UDC 630*431.1(497.11); 551.58(497.11)"1981/2010"

COBISS.SR-ID: 219338252

Original research paper

Acta Agriculturae Serbica, Vol. XX, 39 (2015), 17-28

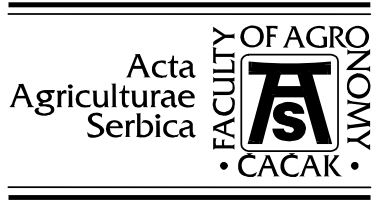

\title{
Evaluating the impact of climate on forest vulnerability to fires
}

\author{
Stanimir Živanović \\ Emergency Management Sector of Serbia, BELGRADE \\ zivannn@open.telekom.rs
}

\begin{abstract}
The assessment of the threat of forest fires usually includes identification of factors and quantification of risk levels. This work presents an approach to modeling the risk of forest fires caused by climate impacts. Climate Impact Assessment is based on the significance of air temperature, rainfall and relative air humidity. The analysis is based on the meteorological data obtained from 26 meteorological stations in Serbia for the period from 1981 to 2010 . The analysis is used to predict the areas where the expected rate of fire is high. The method is simple; it describes the key variables for the risk under climate impacts and the spatial pattern of risk. It is suitable for operational use by authorized services. The risk of forest fire is classified as negligible, small, medium and large.

The database and analysis results were used to build the matrix of risk assessment of forest fires in Serbia. A great part of the territory of Serbia is relatively highly sensitive to forest fires. The lowest consequences of climate impacts are visible in the areas of Kopaonik and Zlatibor. In Serbia, there is no place where there is a negligible risk of fire. Further research, especially in terms of the relationship between climate change and the adaptive capacity of existing forest ecosystems, species and existing genotypes, is urgently needed in Serbia.
\end{abstract}

Key words: climate, fire, forestry. 
Acta Agriculturae Serbica, Vol. XX, 39 (2015); 17-28

\section{Introduction}

Climate and its influence play an important role in the threat of forest fire occurrence. Many authors (Pyne et al. 1996, Flannigan and Wotton 2001, M. Flannigan et al. 2009, Živanović 2010, Allen CD et al. 2010 Xystrakis et al. 2013) suggest that the occurrence of fire depends on climate and humidity of combustible materials. Martin et al. (2001) hold the opinion that fire is closely associated with climate. The greatest risk of fire appears during summer months, when air temperatures are high, and the moisture content in the air is reduced (Živanović 2014). Areas with the average annual air temperature above $12^{\circ} \mathrm{C}$, rainfall up to $800 \mathrm{~mm} / \mathrm{m}^{2}$ and the average annual relative humidity up to $70 \%$ are especially vulnerable to fire.

Balance of plant cover mostly depends on air temperature and precipitation. As a climate element, temperature has a dominant impact on vegetation and the possibility of the emergence and spread of a fire. The probability of a forest fire depends, inter alia, on total rainfall (Ćurić et al. 2013). Trends in the deficit and surplus of daily, monthly and annual rainfall affect the status of combustible materials and the possibility of fire (Ćurić and Živanović 2013).

Based on the available climate data, it is possible to derive relevant information about forest fire potential in a given area (Chandler C et al. 1983). Today, a great number of methods are being used for risk assessment of the outbreak and spread of forest fires.

The aim of this work is to perform multi-criteria evaluation of the impact of climate change as a factor that affects the vulnerability of forests to fires.

\section{Materials and methods}

Eastern Serbia is located in southeastern Europe between $18^{\circ} 39^{\prime}$ and $23^{\circ} 01^{\prime}$ East latitude and $41^{\circ} 51^{\prime}$ and $46^{\circ} 11^{\prime}$ North longitude. The Republic of Serbia covers an area of $88,361 \mathrm{~km}^{2}$ with $7,186,862$ inhabitants according to the 2011 Census.

Winters in Serbia are short and cold, and summers are warm. The coldest month is January and the warmest is July. The average altitude is $470 \mathrm{~m}$. The forest coverage in Serbia is approximately $29.1 \%$ of the territory, with deciduous species dominating.

For the analysis, the data of ground-based meteorological measurements obtained from 26 meteorological stations in the Republic of Serbia were used. To assess the risk of forest fires due to climate impact, we used data on the average values of air temperature, precipitation and relative air humidity for the period 1981- 2010. 


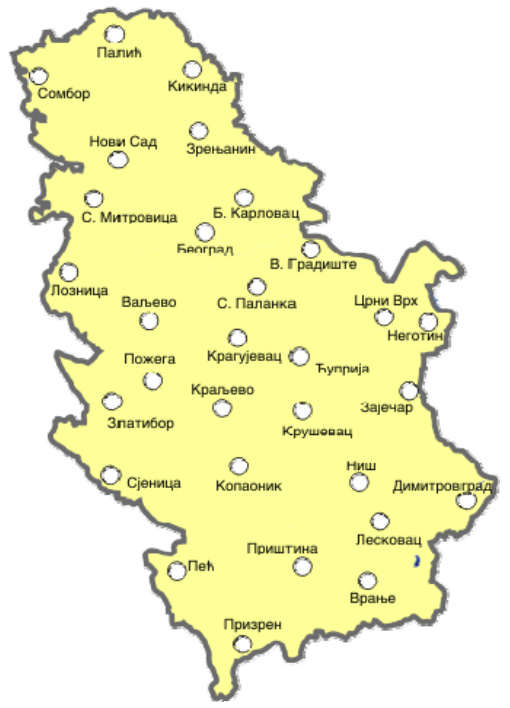

Figure 1. Synoptic Network stations in Serbia

Processing climate data elements provides an opportunity to define the risk of forest fires. Evaluation of the impact of air temperature, precipitation and relative humidity on the risk of fires was performed by ranking threats as minor, small, medium and high significance risks.

\section{General characteristics of climate in Serbia}

\section{Basic characteristics of air temperature}

The temperature model provides the basic climate characteristics of an area and has a direct or an indirect influence on the values of other meteorological elements. High air temperatures affect the physiologically weakening and drying vegetation (Otorepec Silva, 1991, Craig et al. 2010). Forest trees with shallow roots living on sunny slopes are especially sensitive to the effects of this factor (Maria et al. 2004).

Table 1. presents values of average monthly and annual air temperatures across meteorological stations for the 1981-2010 research period (www.hidmet.gov.rs).

Table 1. shows that the average annual air temperature in Serbia is $10.5^{\circ} \mathrm{C}$. Air temperatures indicate that for 20 stations air temperature is higher than the national average. Lower values are in areas at higher altitudes. Average monthly values for air temperature during the growing season in most meteorological stations are higher than $10{ }^{\circ} \mathrm{C}$, when the risk of forest fires is increased. The hottest period is July, with an average daily temperature above $20^{\circ} \mathrm{C}$ at 22 measuring points. The coldest period is in January, even at 11 stations, with the measured temperatures lower than $0{ }^{\circ} \mathrm{C}$. 
Acta Agriculturae Serbica, Vol. XX, 39 (2015); 17-28

\section{Basic characteristics of precipitation}

The formation, development and composition of forest communities are caused, among other reasons, by the precipitation regime. The distribution and quantity of precipitation affect the moisture content of combustible materials (Ćurić and Živanović, 2013) and thus reduce the risk of fire and vice versa. According to Trabaud (1980), the quantity and distribution of rainfall is an important climatic factor influencing the spread of fire.

Trabaud observed that the number of fires is exponentially decreasing with precipitation.

The average annual value of precipitation in Serbia for the period 1981-2010 is $681.4 \mathrm{~mm}$.

Table 2. shows that the measured values of precipitation at 9 meteorological stations are higher than the national average value. The comparison of data on monthly precipitation shows asymmetrical values for February and June, at a ratio of $1: 2$.

Table 2. shows average monthly and annual precipitation for the period 1981-2010. (www.hidmet.gov.rs).

\section{Main characteristics of relative humidity}

Moisture content in the air is an element that affects combustible materials condition. Dry air with low relative humidity increases the coefficient of evaporation and transpiration, and thus decreases the moisture content of the fuel material, and vice versa. Humid air, due to high relative moisture, does not absorb moisture from the material but returns it, causing the material to become less flammable. Low relative humidity means increased water loss from plants by transpiration, and photosynthesis decreases, causing the plant to wilt and dry, if water requirements cannot be recovered from the soil.

From the standpoint of fire protection, particularly interesting are prolonged periods of low moisture content in the air, when fire risk is increased. Data on the average monthly and annual average values of relative humidity in Serbia are presented in Table 3. (www.hidmet.gov.rs).

The analysis of Table 3. data shows that the relative humidity is lowest in the warmest summer months, and the highest in the coldest winter months. The numeric values indicating relative humidity decrease from winter to summer, and then increase again from summer to winter.

The average annual relative humidity of the respective meteorological stations ranges from 68 to $80 \%$, which indicates a medium level of saturation of the ground layer of air with water vapor. 
Acta Agriculturae Serbica, Vol. XX, 39 (2015); 17-28

Table 1. Average monthly and annual air temperature $\left({ }^{\circ} \mathrm{C}\right)$ for meteorological stations in Serbia for the 1981-2010 period of analysis.

\begin{tabular}{|c|c|c|c|c|c|c|c|c|c|c|c|c|c|}
\hline \multirow{2}{*}{$\begin{array}{l}\text { Station } \\
\text { /Area }\end{array}$} & \multicolumn{12}{|c|}{ Month } & \multirow[b]{2}{*}{ Years } \\
\hline & 1 & 2 & 3 & 4 & 5 & 6 & 7 & 8 & 9 & 10 & 11 & 12 & \\
\hline Negotin & 0.3 & 1.9 & 6.6 & 12.2 & 17.7 & 21.3 & 23.5 & 22.8 & 17.6 & 11.6 & 5.5 & 1.1 & 11.8 \\
\hline Zrenjanin & 0.1 & 1.6 & 6.4 & 12.0 & 17.4 & 20.3 & 22.2 & 21.8 & 17.1 & 11.9 & 6.0 & 1.4 & 11.5 \\
\hline $\begin{array}{l}\text { Veliko } \\
\text { Gradište }\end{array}$ & 0.1 & 1.5 & 6.2 & 11.8 & 17.0 & 19.9 & 21.9 & 21.5 & 16.8 & 11.7 & 6.0 & 1.4 & 11.3 \\
\hline Kikinda & -0.2 & 1.4 & 6.3 & 11.9 & 17.3 & 20.3 & 22.3 & 21.7 & 16.9 & 11.6 & 5.6 & 1.1 & 11.3 \\
\hline $\begin{array}{l}\text { Sremska } \\
\text { Mitrovica }\end{array}$ & 0.1 & 1.6 & 6.4 & 11.8 & 17.2 & 19.9 & 21.5 & 21.2 & 16.6 & 11.7 & 5.8 & 1.4 & 11.3 \\
\hline Novi Sad & 0.2 & 1.6 & 6.4 & 11.8 & 17.3 & 20.1 & 21.9 & 21.6 & 16.9 & 11.8 & 5.9 & 1.5 & 11.4 \\
\hline Sombor & -0.1 & 1.4 & 6.2 & 11.6 & 17.1 & 20.2 & 21.9 & 21.3 & 16.5 & 11.3 & 5.4 & 1.1 & 11.2 \\
\hline Zaječar & -0.2 & 1.2 & 5.9 & 11.4 & 16.8 & 20.4 & 22.4 & 21.7 & 16.6 & 10.8 & 4.8 & 0.7 & 11.0 \\
\hline Palić & -0.4 & 1.3 & 6.0 & 11.6 & 17.3 & 20.4 & 22.3 & 21.7 & 16.8 & 11.4 & 5.4 & 0.8 & 11.2 \\
\hline Belgrade & 1.4 & 3.1 & 7.6 & 12.9 & 18.1 & 21.0 & 23.0 & 22.7 & 18.0 & 12.9 & 7.1 & 2.7 & 12.5 \\
\hline Kraljevo & 0.3 & 2.3 & 6.8 & 11.8 & 16.7 & 19.8 & 21.8 & 21.5 & 16.8 & 11.8 & 6.0 & 1.6 & 11.5 \\
\hline Požega & -1.6 & 0.4 & 5.3 & 10.2 & 15.2 & 18.3 & 20.0 & 19.5 & 15.1 & 10.2 & 4.1 & -0.4 & 9.7 \\
\hline Kopaonik & -4.6 & -5.1 & -2.2 & 2.0 & 7.3 & 10.6 & 12.7 & 12.8 & 8.7 & 5.0 & 0.0 & -3.5 & 3.6 \\
\hline Leskovac & 0.0 & 1.7 & 6.4 & 11.4 & 16.4 & 19.7 & 21.6 & 21.2 & 16.3 & 11.2 & 5.5 & 1.4 & 11.1 \\
\hline S. Palanka & 0.7 & 2.1 & 6.5 & 11.8 & 17.0 & 20.1 & 22.0 & 21.6 & 16.8 & 11.7 & 6.2 & 1.9 & 11.5 \\
\hline Ćuprija & 0.2 & 1.6 & 6.1 & 11.5 & 16.7 & 19.7 & 21.5 & 21.3 & 16.5 & 11.4 & 5.8 & 1.5 & 11.1 \\
\hline Vranje & -0.1 & 1.8 & 6.4 & 11.2 & 16.0 & 19.5 & 21.6 & 21.6 & 16.9 & 11.8 & 5.7 & 1.2 & 11.1 \\
\hline Valjevo & 0.6 & 2.0 & 6.6 & 11.6 & 16.8 & 19.9 & 21.9 & 21.4 & 16.8 & 11.7 & 6.1 & 1.9 & 11.4 \\
\hline Zlatibor & -2.1 & -1.3 & 2.4 & 7.2 & 12.3 & 15.4 & 17.2 & 17.5 & 13.1 & 8.8 & 3.2 & -1.2 & 7.7 \\
\hline Kruševac & 0.2 & 2.0 & 6.6 & 11.8 & 16.8 & 20.0 & 21.8 & 21.5 & 16.8 & 11.6 & 5.9 & 1.6 & 11.4 \\
\hline $\begin{array}{c}\text { Kragujeva } \\
\text { c }\end{array}$ & 0.9 & 2.3 & 6.6 & 11.7 & 16.7 & 20.0 & 21.9 & 21.5 & 16.9 & 11.9 & 6.4 & 2.1 & 11.6 \\
\hline Sjenica & -3.6 & -2.7 & 1.8 & 6.5 & 11.5 & 14.7 & 16.5 & 16.2 & 11.9 & 7.8 & 2.2 & -2.1 & 6.7 \\
\hline Loznica & 0.8 & 2.4 & 6.9 & 11.8 & 17.0 & 20.0 & 21.8 & 21.4 & 16.8 & 11.9 & 6.3 & 2.2 & 11.6 \\
\hline $\begin{array}{l}\text { Dimitrovg } \\
\text { rad }\end{array}$ & -0.7 & 0.6 & 5.0 & 10.1 & 14.9 & 18.2 & 20.1 & 19.8 & 15.3 & 10.5 & 5.0 & 0.8 & 10.0 \\
\hline Niš & 0.6 & 2.4 & 7.0 & 12.2 & 17.1 & 20.4 & 22.5 & 22.3 & 17.4 & 12.3 & 6.4 & 2.1 & 11.9 \\
\hline Crni Vrh & -3.5 & -3.0 & 0.8 & 6.2 & 11.7 & 14.7 & 16.9 & 17.0 & 12.2 & 7.3 & 1.6 & -2.3 & 6.6 \\
\hline $\begin{array}{l}\text { Area } \\
\text { Serbia }\end{array}$ & -0.4 & 1.0 & 5.5 & 10.7 & 15.9 & 19.0 & 20.9 & 20.6 & 15.9 & 10.9 & 5.1 & 0.8 & 10.5 \\
\hline
\end{tabular}


Acta Agriculturae Serbica, Vol. XX, 39 (2015); 17-28

Table 2. Average monthly and annual precipitation $(\mathrm{mm})$ for the meteorological stations in Serbia for the 1981-2010 period of analysis

\begin{tabular}{|c|c|c|c|c|c|c|c|c|c|c|c|c|c|}
\hline \multirow{2}{*}{$\begin{array}{l}\text { Station/ } \\
\text { Area }\end{array}$} & \multicolumn{12}{|c|}{ Month } & \multirow[b]{2}{*}{ Years } \\
\hline & 1 & 2 & 3 & 4 & 5 & 6 & 7 & 8 & 9 & 10 & 11 & 12 & \\
\hline Negotin & 41.8 & 44.1 & 47.6 & 53.5 & 50.8 & 59.2 & 49.4 & 47.5 & 45.4 & 49.5 & 58.4 & 66.4 & 613.6 \\
\hline Zrenjanin & 35.9 & 30.0 & 37.2 & 43.2 & 55.4 & 88.8 & 60.0 & 45.4 & 50.2 & 43.9 & 47.8 & 45.3 & 583.2 \\
\hline $\begin{array}{l}\text { Veliko } \\
\text { Gradište }\end{array}$ & 45.0 & 42.2 & 41.5 & 57.2 & 59.8 & 81.6 & 61.4 & 55.9 & 57.5 & 51.8 & 48.4 & 50.7 & 653.0 \\
\hline Kikinda & 34.3 & 26.8 & 33.1 & 43.8 & 53.9 & 75.5 & 56.1 & 49.6 & 50.4 & 41.1 & 45.2 & 46.5 & 556.3 \\
\hline $\begin{array}{l}\text { Sremska } \\
\text { Mitrovica }\end{array}$ & 37.9 & 29.2 & 40.4 & 48.4 & 56.2 & 84.4 & 61.6 & 52.8 & 50.3 & 54.6 & 52.8 & 45.6 & 614.2 \\
\hline Novi Sad & 39.1 & 31.4 & 42.5 & 49.2 & 63.0 & 91.4 & 64.3 & 57.5 & 53.8 & 52.7 & 53.8 & 48.8 & 647.3 \\
\hline Sombor & 37.3 & 29.9 & 36.4 & 45.2 & 60.0 & 81.5 & 66.2 & 53.1 & 54.4 & 47.3 & 53.7 & 47.4 & 612.4 \\
\hline Zaječar & 38.4 & 39.8 & 40.6 & 53.2 & 52.4 & 58.1 & 56.3 & 43.9 & 44.3 & 48.0 & 52.3 & 54.0 & 581.4 \\
\hline Palić & 33.4 & 30.3 & 33.9 & 44.0 & 55.5 & 80.5 & 57.4 & 52.2 & 49.7 & 39.6 & 48.1 & 46.5 & 571.1 \\
\hline Belgrade & 46.9 & 40.0 & 49.3 & 56.1 & 58.0 & 101.2 & 63.0 & 58.3 & 55.3 & 50.2 & 55.1 & 57.4 & 690.9 \\
\hline Kraljevo & 45.1 & 45.4 & 52.9 & 62.6 & 71.2 & 92.2 & 76.8 & 64.9 & 59.1 & 57.3 & 56.6 & 56.1 & 740.3 \\
\hline Požega & 42.7 & 41.9 & 45.8 & 58.0 & 74.8 & 88.4 & 76.3 & 59.6 & 65.8 & 57.1 & 63.5 & 52.3 & 726.4 \\
\hline Kopaonik & 60.3 & 65.9 & 74.9 & 88.7 & 110.6 & 107.1 & 91.2 & 80.3 & 85.6 & 67.8 & 78.3 & 73.8 & 984.4 \\
\hline Leskovac & 42.2 & 45.7 & 45.9 & 60.5 & 55.8 & 64.1 & 44.2 & 47.3 & 51.4 & 51.1 & 61.9 & 55.2 & 625.4 \\
\hline $\begin{array}{l}\text { Smed. } \\
\text { Palanka }\end{array}$ & 42.4 & 39.2 & 43.6 & 50. & 54.3 & 78.7 & 60.5 & 58.9 & 56.4 & 51.2 & 50.0 & 51.8 & 637.2 \\
\hline Ćuprija & 46.1 & 45.4 & 45.1 & 60.6 & 64.1 & 80.2 & 57.0 & 46.6 & 52.2 & 50.6 & 53.8 & 56.5 & 658.2 \\
\hline Vranje & 35.4 & 38.3 & 38.2 & 52.0 & 56.3 & 63.2 & 44.7 & 43.2 & 46.7 & 52.4 & 57.4 & 50.5 & 578.3 \\
\hline Valjevo & 49.9 & 44.6 & 57.9 & 59.9 & 72.1 & 110.2 & 71.0 & 70.7 & 65.3 & 62.9 & 62.7 & 60.6 & 787.7 \\
\hline Zlatibor & 65.4 & 68.5 & 73.4 & 79.0 & 94.4 & 110.2 & 96.3 & 78.8 & 98.3 & 78.2 & 92.3 & 82.6 & 1017.3 \\
\hline Kruševac & 40.3 & 39.2 & 48.4 & 56.6 & 56.9 & 71.2 & 55.0 & 49.8 & 50.0 & 49.3 & 56.2 & 55.1 & 628.1 \\
\hline Kragujevac & 37.9 & 37.0 & 42.3 & 53.9 & 58.7 & 76.4 & 57.7 & 58.6 & 51.6 & 48.9 & 49.5 & 45.8 & 618.5 \\
\hline Sjenica & 46.3 & 47.4 & 46.4 & 55.7 & 71.5 & 79.1 & 66.9 & 62.0 & 75.6 & 62.4 & 74.1 & 62.2 & 749.5 \\
\hline Loznica & 59.3 & 46.0 & 65.7 & 62.8 & 78.2 & 108.5 & 85.2 & 75.2 & 69.5 & 73.5 & 74.4 & 69.6 & 868.0 \\
\hline Dimitrovgrad & 39.5 & 38.1 & 40.2 & 54.3 & 67.2 & 70.0 & 61.1 & 52.5 & 51.8 & 50.2 & 52.8 & 46.9 & 624.7 \\
\hline Niš & 38.8 & 36.8 & 42.5 & 56.6 & 58.0 & 57.3 & 44.0 & 46.7 & 48.0 & 45.5 & 54.8 & 51.5 & 580.3 \\
\hline Crni Vrh & 47.6 & 46.0 & 50.2 & 69.8 & 77.4 & 93.0 & 68.5 & 61.3 & 67.8 & 66.5 & 61.7 & 59.4 & 769.1 \\
\hline Area Serbia & 43.4 & 41.1 & 46.8 & 56.7 & 64.9 & 82.8 & 63.5 & 56.6 & 57.9 & 54.0 & 58.3 & 55.3 & 681.4 \\
\hline
\end{tabular}

Table 3. shows that at 15 meteorological stations relative humidity values are lower than the national average value. Monthly values of relative humidity are variables from $61 \%$ up to $88 \%$ from dry to very high relative humidity. Within the analyzed area, the relative humidity in the range between $70 \%$ and $75 \%$ is an indicator of dry weather. 
Acta Agriculturae Serbica, Vol. XX, 39 (2015); 17-28

Table 3. Average monthly and annual relative humidity (\%) for the meteorological stations in Serbia for the 1981-2010 period.

\begin{tabular}{|c|c|c|c|c|c|c|c|c|c|c|c|c|c|}
\hline \multirow{2}{*}{ Station/Area } & \multicolumn{12}{|c|}{ Month } & \multirow{2}{*}{ Years } \\
\hline & 1 & 2 & 3 & 4 & 5 & 6 & 7 & 8 & 9 & 10 & 11 & 12 & \\
\hline Negotin & 80 & 75 & 69 & 66 & 66 & 63 & 60 & 62 & 69 & 76 & 81 & 83 & 71 \\
\hline Zrenjanin & 85 & 78 & 70 & 66 & 65 & 67 & 66 & 66 & 71 & 74 & 81 & 86 & 73 \\
\hline Veliko Gradište & 83 & 77 & 69 & 67 & 68 & 70 & 68 & 67 & 72 & 74 & 78 & 83 & 73 \\
\hline Kikinda & 86 & 80 & 71 & 66 & 64 & 66 & 64 & 65 & 71 & 75 & 82 & 87 & 73 \\
\hline Sremska Mitrovica & 87 & 81 & 73 & 69 & 68 & 71 & 71 & 71 & 75 & 78 & 85 & 88 & 76 \\
\hline Novi Sad & 85 & 79 & 71 & 67 & 66 & 69 & 68 & 68 & 72 & 76 & 82 & 86 & 74 \\
\hline Sombor & 84 & 78 & 70 & 66 & 64 & 65 & 64 & 66 & 71 & 75 & 82 & 86 & 72 \\
\hline Zaječar & 79 & 75 & 71 & 69 & 69 & 68 & 64 & 66 & 71 & 78 & 81 & 82 & 73 \\
\hline Palić & 85 & 79 & 71 & 66 & 64 & 64 & 62 & 64 & 70 & 75 & 82 & 87 & 72 \\
\hline Belgrade & 78 & 71 & 63 & 61 & 61 & 63 & 61 & 61 & 67 & 71 & 75 & 79 & 68 \\
\hline Kraljevo & 81 & 75 & 69 & 66 & 69 & 70 & 68 & 68 & 74 & 77 & 79 & 83 & 73 \\
\hline Požega & 86 & 80 & 74 & 71 & 73 & 75 & 74 & 75 & 79 & 82 & 85 & 87 & 78 \\
\hline Kopaonik & 81 & 83 & 82 & 80 & 79 & 79 & 75 & 74 & 80 & 80 & 81 & 84 & 80 \\
\hline Leskovac & 82 & 77 & 70 & 68 & 69 & 68 & 65 & 66 & 73 & 77 & 81 & 83 & 73 \\
\hline Smederevska Palanka & 81 & 75 & 68 & 66 & 67 & 68 & 66 & 66 & 72 & 75 & 78 & 82 & 72 \\
\hline Ćuprija & 82 & 77 & 71 & 68 & 69 & 70 & 68 & 67 & 73 & 77 & 79 & 83 & 74 \\
\hline Vranje & 81 & 75 & 67 & 64 & 65 & 65 & 61 & 60 & 67 & 73 & 79 & 83 & 70 \\
\hline Valjevo & 82 & 76 & 70 & 68 & 68 & 70 & 67 & 69 & 74 & 78 & 80 & 82 & 74 \\
\hline Zlatibor & 83 & 79 & 74 & 70 & 70 & 73 & 70 & 70 & 75 & 78 & 80 & 85 & 76 \\
\hline Kruševac & 85 & 79 & 73 & 71 & 72 & 72 & 70 & 69 & 74 & 79 & 81 & 85 & 76 \\
\hline Kragujevac & 79 & 75 & 69 & 67 & 68 & 68 & 65 & 67 & 72 & 75 & 77 & 81 & 72 \\
\hline Sjenica & 82 & 80 & 77 & 72 & 72 & 73 & 72 & 73 & 78 & 79 & 81 & 84 & 77 \\
\hline Loznica & 83 & 78 & 71 & 69 & 69 & 71 & 69 & 71 & 76 & 80 & 82 & 84 & 75 \\
\hline Dimitrovgrad & 81 & 77 & 70 & 67 & 69 & 70 & 66 & 66 & 71 & 75 & 79 & 82 & 73 \\
\hline Niš & 80 & 74 & 66 & 63 & 65 & 65 & 61 & 61 & 69 & 73 & 77 & 81 & 70 \\
\hline Crni Vrh & 85 & 84 & 79 & 74 & 73 & 75 & 72 & 70 & 77 & 82 & 85 & 86 & 78 \\
\hline Area Serbia & 83 & 78 & 71 & 68 & 68 & 69 & 67 & 67 & 73 & 77 & 81 & 84 & 74 \\
\hline
\end{tabular}

Based on these tabulated data (Table 3), the highest moisture content was measured in the Kopaonik area, and the lowest in the Belgrade area. Monthly values indicate that in most areas in Serbia, during July and August, the lowest moisture content in the air was measured.

Selection of criteria and methods for evaluating the impact of climate on the risk of forest fire

After identifying climate-related aspects, it is necessary to define criteria for evaluating the significance of their impact on the risk of forest fires.

Assessment of climate significance involves determination of the significance of climate-related aspects in the probability of fire occurrence and 
the expected rate of uncontrolled growth and spread of fire. It should be considered that the significance of the climate impact on the risk of forest fires is relative and, as such, it is not defined in absolute terms. Criteria for climate conditions are the levels (values) of significance.

In this case, the method of significance ranking has been put in relation to the calculation of the risk of forest fires, Tables 4, 5 and 6 .

The assessment of the risk of forest fires due to climate impact involves the evaluation of the impact of air temperature, precipitation and relative humidity.

The most vulnerable areas are those with the average annual air temperature above $12^{\circ} \mathrm{C}$, precipitation of $800 \mathrm{~mm} / \mathrm{m}^{2}$, and average annual relative humidity up to $70 \%$.

In terms of climate impact, according to this model, the least affected are the areas with air temperature up to $9^{\circ} \mathrm{C}$, precipitation over $1200 \mathrm{~mm}$ and relative humidity over $80 \%$.

Table 4. Significance of the air temperature factor (SATF)

\begin{tabular}{llc}
\hline $\begin{array}{l}\text { The average annual air temperature, } \\
{ }^{\circ} \mathrm{C}\end{array}$ & Estimation of fire incidence rate & Rating \\
Over 12 & expected high fire rate & 3 \\
$9.1-12.0$ & expected average fire rate & 2 \\
up to 9 & expected low fire rate & 1 \\
\hline
\end{tabular}

Table 5. Significance of the precipitation factor (SPF)

\begin{tabular}{llc}
\hline $\begin{array}{l}\text { The average annual precipitation, } \\
\mathrm{mm} \mathrm{m}^{-2}\end{array}$ & Estimation the of fire incidence rate & Rating \\
up to 800 & expected high fire incidence rate & 3 \\
$801-1200$ & expected average fire incidence rate & 2 \\
More than 1200 & expected low fire incidence rate & 1 \\
\hline
\end{tabular}

Table 6. Humidity significance factor (HSF)

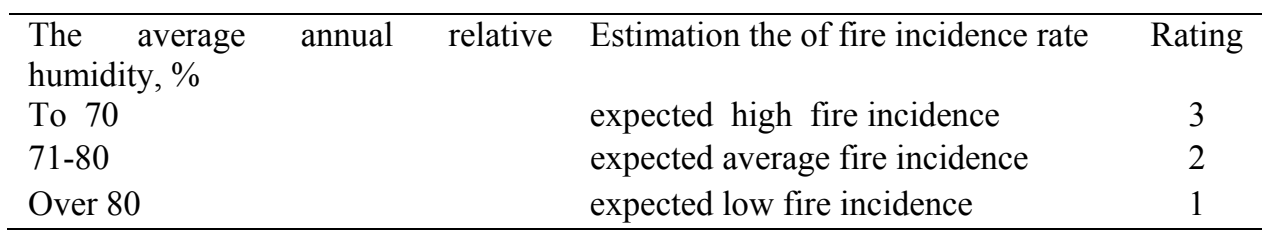

The overall forest fire risk factor caused by climate impact is estimated on the basis of the elements of air temperature, rainfall and relative humidity impacts, ranked from the lowest to the highest effect. The risk of forest fires in terms of climate impact is calculated as the sum of probabilities of the 
significance of average annual air temperature, the significance of average annual precipitation and the significance of relative humidity, as follows:

$$
\mathrm{R}=(\mathrm{SATF}+\mathrm{SPF}+\mathrm{HSF}) .
$$

Based on this classification, risk (R) can be categorized as negligible, small, medium and high, as follows:

$$
\begin{array}{ll}
1 \leq \mathrm{R} \leq 3 & \text { negligible } \\
3<\mathrm{R} \leq 5 & \text { small } \\
5<\mathrm{R} \leq 7 & \text { medium } \\
7<\mathrm{R} \leq 9 & \text { high. }
\end{array}
$$

Formula (1) is used to identify the risk of forest fires due to climate impact for areas in Serbia.

Table 7. Risk assessment matrix

\begin{tabular}{lcccclcccc}
\hline Station & ZPF & ZATF & HSF & R & Station & ZPF & ZATF & HSF & R \\
\hline Negotin & 3 & 2 & 2 & 7 & $\begin{array}{l}\text { Smederevska } \\
\text { Palanka }\end{array}$ & 3 & 2 & 2 & 7 \\
Zrenjanin & 3 & 2 & 2 & 7 & Ćuprija & 3 & 2 & 2 & 7 \\
Veliko & 3 & 2 & 2 & 7 & Vranje & 3 & 2 & 2 & 7 \\
Gradište & & & & & & & & & \\
Kikinda & 3 & 2 & 2 & 7 & Valjevo & 3 & 2 & 2 & 7 \\
Sremska & 3 & 2 & 2 & 7 & Zlatibor & 2 & 1 & 2 & 5 \\
Mitrovica & & & & & & & & & \\
Novi Sad & 3 & 2 & 2 & 7 & Krugujevac & 3 & 2 & 2 & 7 \\
Sombor & 3 & 2 & 2 & 7 & Kragujevac & 3 & 2 & 2 & 7 \\
Zaječar & 3 & 2 & 2 & 7 & Sjenica & 3 & 1 & 2 & 6 \\
Palić & 3 & 2 & 2 & 7 & Loznica & 2 & 2 & 2 & 6 \\
Belgrade & 3 & 3 & 3 & 9 & Dimitrovgrad & 3 & 2 & 2 & 7 \\
Kraljevo & 3 & 2 & 2 & 7 & Niš & 3 & 2 & 2 & 7 \\
Požega & 3 & 2 & 2 & 7 & Crni Vrh & 3 & 1 & 2 & 6 \\
Kopaonik & 2 & 1 & 2 & 5 & Area Serbia & 2 & 2 & 2 & 6 \\
Leskovac & 3 & 2 & 2 & 7 & & & & & \\
\hline
\end{tabular}


Table 7. shows that the consequences of climate impacts on forests are the lowest in the areas of Kopaonik and Zlatibor. According to this model, the risk of forest fires from climate impacts is the largest in the Belgrade area. Most of the territory of Serbia has a medium risk of forest fires.

The data obtained using this model are based on the long-term average for 1981-2010. In certain years, differences in average values for climatic elements were recorded, which affected the condition of combustible materials and forest fire risk levels.

\section{Conclusion}

In forestry science and practice, efforts are constantly being made to protect forests from fire, in order to make them integral and continual as well as to improve the methodology of fire control.

Effective monitoring of the impact of climate on vegetation in the region is critical to forecasting and management of the forest potential. If the impact of climate change on plant vegetation is implemented in the risk assessment of forest fires, adverse effects can be minimized.

The analysis under this model indicates that in Serbia there is no place where there is no likelihood of a forest fire. A large part of this area shows relatively medium sensitivity to forest fires. Fire danger is greater if lower precipitation is recorded, especially during periods when air temperatures are extremely high.

Research in genetics and bioengineering may have an important place in the development of forest fire protection. New plant species in certain areas can compensate for unfavorable microclimatic conditions, and thus contribute to a reduction in forest fire risk levels.

\section{References}

Allen C.D., Macalady A.K., Chenchouni H., Bachelet D., McDowell N., Vennetier M., Kitzberger T., Rigling A., Breshears D.D., Hogg E.H.(T.), Gonzalez P., Fensham R., Zhang Z., Castro J., Demidova N., Lim J.-H., Allard G., Running W.S., Semerci A., Cobb N. (2010) A global overview of drought and heat-induced tree mortality reveals emerging climate change risks for forests, Forest Ecology and Management, Volume 259, Issue 4, Pages 660-684

Chandler C., Cheney P., Thomas P., Trabaud L.,Williams D. (1983) Fire in forestry vol.I Forest Fire: Behavior and Effects, USA.

Craig D. Allen, Alison K. Macalady, Haroun Chenchouni, Dominique Bachelet, Nate McDowell, Michel Vennetier, Thomas Kitzberger, Andreas Rigling, David D. Breshears, E.H. (Ted) Hogg, Patrick Gonzalez, Rod Fensham, Zhen Zhang, Jorge Castro, Natalia Demidova, Jong-Hwan Lim, Gillian Allard, Steven W. Running, 
Akkin Semerci, Neil Cobb (2010) A global overview of drought and heat-induced tree mortality reveals emerging climate change risks for forests, Forest Ecology and Management Volume 259, Issue 4, Pages 660-684

Dragićević, S. , Filipović, D. , Kostadinov, S. , Ristić, R. , Novković, I. , Živković, N. , Andjelković, G, Abolmasov, B., Secerov, V. and Djurdjić, S, (2011) Natural Hazard Assessment for Land-use Planning in Serbia, Int. J. Environ. Res., 5(2):371-380,

Flannigan M., Stocks B., Turetsky M., Wotton M. (2009) Impacts of climate change on fire activity and fire management in the circumboreal forest, Global Change Biology, Volume 15, Issue 3, pages 549-560,

Flannigan, M. D., Wotton, B. M. (2001) Climate, Weather and Area Burned, Forest Fires, Behavior and Ecological Effects, Academic Press, San Diego,

Xystrakis F, Koutsias N (2013) Differences of fire activity and their underlying factors among vegetation formations in Greece, iForest vol. 6, pp. 132-140

Maria Laura Suares, Luciana Ghermandi Thomas Kitzberger (2004) Factors predisposing episodic drought-induced tree mortality in Nothofagus - site, climatic sensitivity and growth trends, Journal of Ecology Volume 92, Issue 6, pages 954-966

Martín De Luís', Maria Francisca García-Cano, Jordi Cortina, José Raventós,José Carlos González-Hidalgo, Juan Rafael Sánchez (2001) Climatic trends, disturbances and short-term vegetation dynamics in a Mediterranean shrubland, Forest Ecology and Management, Volume 147, Issue 1, Pages 25-37

Meteorological Yearbook 1: Climatological Data, for Period $1981 \div 2010$ year. Hidrometeorological Institute of Serbia.

Otorepec Silva (1991) Agrometeorologija, Naučna knjiga Beograd, 222 pp.

Pyne, S., Andrews, P.L. \& Laven, R.D. (1996) Introduction to wildland fire. John Wiley \& Sons, New York-Chichester-Brisbane-Toronto-Singapore. $769 \mathrm{p}$

Trabaud, L. (1980) Impact biologique et écologique des feux de la végétation des zones de garrigues du bas-Languedoc. Thesis. Université des Sciences et Techniques du Languedoc. France.

Ćurić M., Živanović S. (2013) Dependence between Deficit and Surplus of Precipitation and Forest Fires, Disaster Advances, Vol 6(6) pp 64-69

Ćurić M., Živanović S. Darko Z. (2013) Precipitation forecast using statistical approaches FACTA UNIVERSITATIS Series: Working and Living Environmental Protection Vol. 10, No1, 2013, pp. 79-91

Živanović S. (2010) Risk factors for forest fires, Bezbednost Beograd, vol. 52, 179-190,

Živanović S. (2014) Forest fires are a risk factor for plant species, Acta Agriculturae Serbica, Vol. XIX, 37; 71-81

***: URL:http:/WWW.hidmet.gov.rs/, 15.01.2015. 
Acta Agriculturae Serbica, Vol. XX, 39 (2015); 17-28

\title{
VREDNOVANJE UTICAJA KLIME NA UGROŽENOST ŠUMA OD POŽARA
}

\author{
Stanimir Živanović \\ Sektor za vanredne situacije, Kneza Miloša 103, 11000 Beograd, Srbija
}

\section{Rezime}

U procenama ugroženosti šuma od požara, obično se vrši identifikovanje faktora i kvantifikovanje stepena opasnosti. Ovaj rad predstavlja pristup modelovanju rizika šuma od požara od uticaja klime. Procena uticaja klime se vrši na osnovu značajnosti temperature vazduha, količina padavina i relativne vlažnosti vazduha. Analiza je bazirana na meteorološkim podacima dobijenih sa 26 meteorološke stanice u Srbiji za period 1981-2010. godina. Jedna od njegovih koristi je da predvidi područja na kojima se očekuje velika učestalost pojave požara. Metoda je jednostavna, opisuje ključne varijable rizika od uticaja klime i prostorni obrazac rizika. Pogodna je za operativnu upotrebu od strane nadležnih službi. Klasifikacija rizika se rangira od zanemarljivog, preko malog i srednjeg do velikog. Baza podataka i analiza rezultata korišćeni su za izgradnju matrice procene rizika šuma od požara u područjima Srbije. Veći deo područja Srbije je sa relativno srednjom osetljivošću šuma na požare. Težina posledica po šumu od uticaja klime je mala na području Kopaonika i Zlatibora. Na području Srbije nema mesta na kojima je zanemarljiv rizik od požara.

Dalja istraživanja, posebno u odnosima između klimatskih promena i sposobnosti adaptacije postojećih šumskih ekosistema, vrsta i postojećih genotipova, hitno su potrebna u Srbiji

Ključne reči: klima, rizik, požar, šumarstvo. 